\title{
IFRS9 TRANSITION IMPACT ON THE QUALITY OF FINANCIAL REPORTING INFORMATION: A CASE STUDY OF YEMEN COMMERCIAL BANKS
}

\author{
Mahdi Qasem Saeed, Saeed ${ }^{1,2 *}$ \\ ${ }^{1}$ Department of Commerce Dr. Babasaheb Ambedkar Marathwada University \\ ${ }^{2}$ Department of Accounting Taiz University- Yemen.
}

\author{
D. A. Nikam ${ }^{3}$ \\ ${ }^{3}$ Shri Muktanand College Gangapur, Dr. Babasaheb Ambedkar Marathwada University.
}

${ }^{*}$ Corresponding author: Mahdi Qasem Saeed Saeed

Article DOI: https://doi.org/10.36713/epra5989

\begin{abstract}
The purpose of this study is to know the IFRS 9 transition impact on the suitability and reliability of the quality of financial reporting information. A questionnaire was used in data collecting. Out of 92 questionnaires, only 85 were valid and suitable. The data analysis has been done by using SPSS and several statistical methods through descriptive statistics such as averages, standard deviations, and T-test. This study adds to the literature by knowing the IFRS 9 transition impact on the suitability and reliability of the quality of financial reporting information in the commercial banks of Yemen. The study reached that there is a positive relationship between the impact of the adoption of the IFRS9 on the suitability and reliability of the quality of financial reporting information in Yemen commercial banks. Finally, the study was concluded with some recommendations.

KEYWORDS: International Standard Financial Reporting IFRS9, Quality of Financial Reporting Information, Suitability, and Reliability, commercial banks.
\end{abstract}

\section{INTRODUCTION}

The International Financial Reporting Standards (IFRS) are a set of accounting standards entities implemented by various countries across the world, which are gradually replacing the old International Accounting Standards (IAS) (Alali \& Cao, 2010). IFRS aims to make international financial reporting comparisons as simple as possible because every country has its group of accounting rules, over the years, the utilized of IFRS has protruded vastly and internationally accepted standards with more than one acceptance more than 150 countries implemented. IFRS is a universal language for business affairs (Bhattacharjee, 2009). The International Accounting Standards Board (IASB) was established in 2001 and is the independent standard-setting body for the IFRS Foundation (Groff \& Mörec, 2020).

In July 2014, the IASB published the final version of IFRS 9 - Financial Instruments IFRS 9. The final version combined the stages of classification, measurement, impairment, and hedge accounting for the IASB project to replace IAS 39 - Financial Instruments: Recognition and Measurement. One of the main goals of the new standards is to address the concerns that have arisen because of the financial crisis that the loss model incurred by IAS 39 contributed to the delay in recognizing credit losses (Shields et al., 2019).

As far as we know, there are no studies have explained the IFRS 9 transition in the Yemeni context, especially regarding IFRS 9 transition. Our study adds 
to the literature by providing an understanding of the IFRS 9 transition in the commercial banks of Yemen. Commercial banks operating in Yemen have been selected as the study population for their importance in society, as well as the efficiency, and accuracy of the commercial banks. In addition to the rapid response of these banks to the adoption of international standards for financial reporting and the environmental changes resulting from global competition. The structure of the banking system in Yemen consisted of eleven conventional and commercial banks, two specialized, four Islamic, and two microfinance banks.

This paper consists of five sections: section 1 includes the introduction, section 2 presents a brief literature review and hypothesis formulation, section 3 discusses the methodology, section 4 includes the analysis and results of the study, finally, presents the conclusion with some recommendations.

1.1 Study Problem and Questions: The problem of the study focuses on clarifying the IFRS 9 transition impact on the quality of financial reporting information (Relevance and Reliability) in Yemen commercial banks. Therefore, this study attempts to answer the question of what IFRS 9 transition impacts on the suitability and reliability of the quality of financial reporting information in Yemen commercial banks?
1.2 The Study Importance: The study comes from concentrating to know the application of the IFRS9 in the sector of commercial banks in Yemen, and IFRS 9 transition impact on the quality of financial reporting information (Suitability and Reliability).

1.3 Objectives of the Study: The main objective of this study is to highlight knowing the IFRS 9 transition impact on the quality of financial reporting information (Suitability and Reliability) in Yemen commercial banks.

1.4 The Study Hypothesis: Based on the conceptual framework of the study, the hypotheses of the study were formulated and proposed as summarized as follows:

There is no impact of the IFRS 9 transition on the quality of financial reporting information (Suitability and Reliability) in Yemen commercial banks.

The following sub- hypotheses are derived from the above main hypothesis:

H01: There is no impact of the IFRS 9 transition on the suitability of the quality of financial reporting information in Yemen commercial banks.

H02: There is no impact of the IFRS 9 transition on the reliability of the quality of financial reporting information in Yemen commercial banks.

\subsection{The Study Model}

\begin{tabular}{|l|r|}
\hline \multicolumn{1}{|c|}{ Table:1 Study Model } \\
\hline \multicolumn{1}{|c|}{ Independent variables } & \multicolumn{1}{c|}{ Dependent variable } \\
\hline The Impact of the IFRS 9 & The Quality of Financial Reporting Information : \\
transition. & $\begin{array}{l}\text { - The suitability of the quality of financial reporting information. } \\
\text { - The reliability of the quality of financial reporting information. }\end{array}$ \\
\hline
\end{tabular}

\section{LITERATURE REVIEW}

In an increasing adoption of IFRS, commercial, social, and even personal decisions require more reliable, timely, and relevant information (Soderstrom $\&$ Sun, 2007). The IFRS sciences are replete with many studies related to the IFRS9; these studies have been conducted in various areas, environments, and countries. For example, (Khersiat \& Alkabbani, 2020) carried out a study applied to insurance companies listed on the Amman stock exchange. The study conducted by (Saqaf et al., 2017) reported that confirms that there is a statistically significant impact of applying IFRS 9 on the appropriateness of accounting information in the financial statements of insurance companies in Jordan. (Groff \& Mörec, 2020). The results of (Loew et al., 2019) showed that Italian and Greek institutions experienced the strongest impacts of implementing IFRS9. A study conducted by (Alhaija, 2012) revealed that the accountant in Jordanian banks possesses sufficient comprehensive knowledge regarding IFRS 9 to improve decision-making. (Jermakowicz et al., 2018) their study relates to the financial statements of the largest Canadian companies (S \& P / TSX 60) listed on the Toronto Stock Exchange (TSX). The results indicate that the adoption of IFRS in Canada created more related funding for reporting on the book value of equity and net income in postadoption periods. the study conducted by (Beerbaum, \& Piechocki, 2016) resulted according to IFRS 9 these two taxonomies provide the possibility for a starting point for the harmonization and the development of common practice disclosures, which could counteract against heterogeneous financial reporting and the issue of "information overload".

The major challenge of the IFRS9 transition is the expected gap between IFRS 9 transition impact on the suitability and reliability of the quality of financial reporting information. The positive attitude of the staff and their readiness for the transition of IFRS9 is the key to the effective and efficient achievement of suitability and reliability of the quality of financial reporting 
information (Nurunnabi, 2018). (Giner \& Mora, 2019) stated that the ability of the staff to use IFRS 9 by efficiently and effectively relies on the effectiveness of the bank's accounting information system. However, there are some obstacles or constraints to the effective to transition IFRS 9. Therefore, the present systems applied in commercial banks do not meet the Yemeni environmental needs to transition IFRS 9. (Owolabi, 2012) conducted a study to recognize the reality of the impact of International Financial Reporting Standards (IFRS) adoption on the accounting quality of listed companies in Kenya. The study reached that the adoption of IFRS around the world is occurring rapidly to bring about accounting quality improvement through a uniform set of standards for financial reporting.

\section{3. .THE STUDY'S CONCEPTUAL FRAMEWORK}

\subsection{The International Financial Reporting}

Standard IFRS9 "Financial Instruments":

IFRS 9 started as a common project with the Financial Accounting Standards Board (FASB), which promulgates accounting standards in the United States, as a result of the financial crisis of 2008, after that, the boards decided to modify their accounting standards for financial instruments to address perceived deficiencies which were believed to have contributed to the magnitude of the crisis financial (Beerbaum, 2015). During the financial crisis, late recognition of credit losses associated with loans and other financial instruments was identified as a weakness in current accounting standards, which is the main reason for the fact that the impairment present value requirements under IAS 39 are based on an incurred loss model, while not being recognized credit losses until the loss occurs. The new impairment requirements in IFRS 9 are based on the Expected Credit Loss (ECL) model and replace the IAS 39 approach. The amount of ECL recognized depends on the extent of credit deterioration since initial recognition (Gebhardt, 2016).

IFRS9 is one of the IFRS, which includes three main topics: classification and measurement of financial instruments, impairment of financial assets, and hedge accounting (Habawal \& Alokdeh 2018). Financial Reporting Standard (IFRS) was issued by the International Accounting Standards Board (IASB) and is the standard that was imposed on January 1, 2018, to replace the previous IFRS for Financial Instruments, IAS 39 (Hashim et al., 2016).

The IASB issued IFRS 9 Financial Instruments, supplementing its response to the financial crisis by improving the accounting and reporting of financial assets and liabilities (Onali \& Ginesti, 2014). IFRS 9 requires how an item should classify and measure financial assets, financial liabilities, and a few contracts to buy or sell non-financial items, and recognize a financial asset or financial liability in its statement of financial position when it becomes clustered. Legally binding arrangements for the instrument: As a general rule, financial assets and financial liabilities are recognized initially at fair value plus or minus the directly attributable transaction costs, and at the commencement of recognition, a material can measure a financial asset or financial liability at a fair value minus or plus, at the expense of financial liability or unlisted financial asset. At fair value through profit or loss, transaction costs that are directly attributable to the acquisition or issue of the financial asset or financial liability.

\subsection{Characteristics of Financial Reporting Quality:}

Financial reporting quality comes in many shapes and sizes, but they all share certain features. Information in financial reporting according to IFRS financial statements has these characteristics, and IFRSs present several specific characteristics that set them apart from other accounting systems. Suitability is referred to as "the ability to effect change in the decisions that users make as providers of capital" (IASB, 2008: 35). Annual reports play a crucial role in determining the level of suitability by disclosing forward-looking information, disclosing information about business opportunities and risks, and providing feedback on how major market events and significant transactions affect the entities. Therefore, the information suitability in financial reports influences users in their economic decisions (Lay \& Jusoh, 2012).

Reliability and Validity is another critical factor for the quality of financial reports, the information of financial reports must have the quality of reliability to be useful. This quality is achieved when the information that users rely on is free from bias and errors (Herath \& Albarqi, 2017). Financial data can be compared from one period to another or of two companies in the same manufacturer so that you can make informed decisions about the companies, this means that the information should enable users to identify and understand the similarities and differences between the elements (IASB, 2010). The information is comparable if it can be compared with similar information about other entities and with similar information about the same entity for another period or date

Quality of understanding is achieved through effective communication. Thus, the better the understanding of the information from the users, the greater the quality that will be achieved, which is one of the enhanced qualitative characteristics that will increase when the information is presented and classified clearly and adequately. When annual reports are well organized, users can understand their needs (Otusanya et al., 
2013). The use of charts and tables helps to present the information clearly, and the use of language and technical terms can be easily traced. Timing is another enhanced qualitative feature. Timeliness demonstrates that information must be available to decision-makers before it loses its powerful and good influence. When assessing the quality of reports in an annual report, timing is evaluated using the period between the end of the year and the date the auditor's report was issued the period that it took the auditor to sign the report after the fiscal year-end (Owolabi \& Iyoha, 2012). The financial statements are complete and free from bias and error. This means that honest representation information must be complete and include all necessary information description and neutral interpretations, free from bias and manipulation, and free from error. It should represent the honest, upfront information that aims to focus (BPP, 2014). It found that faithful representation decreased after adopting IFRSs at a $1 \%$ significance level. The reason is the extensive use of valuation and fair value associated with IFRSs (Yurisandi \& Puspitasari, 2015).

\section{RESEARCH METHODOLOGY}

The study population consists of commercial banks operating in Yemen amounting to fifteen banks (CBY, 2019). The study covered eight (8) randomly selected banks. A questionnaire was used and distributed to different levels of employees (General Managers, Credit Managers, Finance Managers, Risk Managers, Auditors, and Accountants). Out of 92 questionnaires, only 88 were returned. The number of valid and suitable questionnaires was 85 -yielded $92.4 \%$ responses rate. To score replies, the five Likert scales were used. Data collected were reviewed and analyzed using SPSS software. The selected commercial banks are the National Bank of Yemen; Yemen Bank for Recon. and Dev.; International Bank of Yemen; Yemen Kuwait Bank; Yemen commercial bank; Arab Bank Limited; Yemen Gulf Bank; and Coop. Agricultural Credit Bank.

Table 2: List of commercial banks operating in Yemen.

1. Yemen Bank for Recon. \& Dev.

2. National Bank of Yemen

3. Arab Bank Limited

4. United Bank Limited

5. International Bank of Yemen

6. Yemen Kuwait Bank

7. Coop. Agricultural Credit Bank
8. Yemen Commercial Bank

9. Yemen Gulf Bank

10. Shamil Bank of Yemen \& Bahrain

11. Alkuraimi Islamic Microfinance Bank

12. Housing Credit Bank

13. Al-Rafidayn Bank

14. Qatar National Bank

15. Al-Amal Microfinance Bank

\section{DATA ANALYSIS AND INTERPRETATION}

5.1 Testing of the Stability and Validity of the Study Tool Table 3: Results of the Cronbach's Alpha that tested the internal consistency coefficient

\begin{tabular}{|l|l|c|c|}
\hline No & \multicolumn{1}{|c|}{ Description } & No. Of Questions & Stability \\
\hline 1 & The Adoption of the IFRS 9 Requirements in Commercial Banks & 7 & 0.638 \\
\hline 2 & The Suitability of the Quality of Financial Reporting & 5 & 0.729 \\
\hline 3 & the Reliability of the Quality of Financial Reporting & 6 & 0.774 \\
\hline & All Paragraph & 18 & 0.714 \\
\hline
\end{tabular}

Table 3 shows that the study's vocabulary values ranged between $(0.638-0.774)$, and therefore all values were greater than $(60 \%)$ and acceptable for all questionnaire components. This is an indication of the consistency between the elements of the study tool. Overall, the questionnaire has a stability degree at (0.714). 
5.2 The characteristics of the study sample:

\begin{tabular}{|c|c|c|c|c|}
\hline \multicolumn{5}{|c|}{ Table 4: The Mine Characteristics of the Study Sample } \\
\hline NO & Variable & Category & Frequency & Percentage \% \\
\hline \multirow[b]{3}{*}{1} & \multirow[b]{3}{*}{ Gender } & Male & 62 & 73 \\
\hline & & Female & 23 & 27 \\
\hline & & Total & 85 & $100 \%$ \\
\hline \multirow{5}{*}{2} & \multirow{5}{*}{ Age } & Less than 25 & 21 & 25 \\
\hline & & 26- 35 & 29 & 34 \\
\hline & & $36-45$ & 24 & 28 \\
\hline & & $46-55$ & 11 & 13 \\
\hline & & Total & 85 & $100 \%$ \\
\hline \multirow{4}{*}{3} & \multirow{4}{*}{$\begin{array}{l}\text { Academic } \\
\text { degree }\end{array}$} & Diploma or less & 11 & 13 \\
\hline & & Bachelor & 51 & 60 \\
\hline & & Master & 23 & 27 \\
\hline & & Total & 85 & $100 \%$ \\
\hline \multirow{7}{*}{4} & \multirow{7}{*}{ Job } & General Managers & 8 & 9.4 \\
\hline & & Credit Managers & 8 & 9.4 \\
\hline & & Finance Managers & 8 & 9.4 \\
\hline & & Risk Managers & 8 & 9.4 \\
\hline & & Accountants & 28 & 33 \\
\hline & & Auditors & 25 & 92.4 \\
\hline & & Total & 85 & $100 \%$ \\
\hline \multirow{4}{*}{5} & \multirow{4}{*}{$\begin{array}{c}\text { Years of } \\
\text { Experience }\end{array}$} & Less than 5 years & 24 & 28 \\
\hline & & 5 - Less than 10 years & 36 & 42 \\
\hline & & 10 - Less than 15 years & 25 & 30 \\
\hline & & Total & 85 & $100 \%$ \\
\hline
\end{tabular}

Table (3) shows the main characteristics of the study sample. The gender of the respondents is shown of the 85 respondents, $(73 \%)$ of the respondents were male and (27\%) were female. Regarding Job, the percentage was $33 \%$ for accountants, $29.4 \%$ for auditors, $9.4 \%$ for general managers, finance, credit, and risk managers. That a large part of the study sample has sufficient experience and educational qualifications the percentage of holders of bachelor's and master's degrees was $(87 \%)$ of the study sample. While the percentage of those between 5 years to 10 years of experience was $(42 \%)$ of the study sample.

\subsection{The Descriptive Statistics of the Study Sample and its Variables}

5.3.1 The Extent of the Adoption of the International Financial Reporting Standard IFRS9.

Table 5: Means and Std. deviations of items related to the transition of the IFRS 9 requirements.

\begin{tabular}{|c|c|c|c|c|c|c|}
\hline $\begin{array}{l}\mathbf{N} \\
\mathbf{0}\end{array}$ & Items & Mean & $\begin{array}{c}\text { Stand } \\
\text { deviation }\end{array}$ & $\begin{array}{c}\text { Relative } \\
\text { importance }\end{array}$ & $\begin{array}{l}\text { Applicati } \\
\text { on-level }\end{array}$ & Rank \\
\hline 1 & $\begin{array}{l}\text { The bank classifies financial assets as measured } \\
\text { subsequently at cost depleted. }\end{array}$ & 4.38 & .511 & 87.6 & High & 4 \\
\hline 2 & $\begin{array}{l}\text { Financial liabilities classifies at fair value } \\
\text { through profit or loss. }\end{array}$ & 4.39 & .579 & 87.8 & High & 3 \\
\hline 3 & $\begin{array}{l}\text { Financial instruments are recognized when they } \\
\text { become a party to the contractual process. }\end{array}$ & 3.80 & .856 & 76 & High & 7 \\
\hline 4 & $\begin{array}{l}\text { The equity investment was measured at fair } \\
\text { value. }\end{array}$ & 4.19 & .567 & 83.8 & High & 6 \\
\hline 5 & $\begin{array}{l}\text { The bank is obligated to create a contingency } \\
\text { reserve for future losses on all the bank's } \\
\text { financial assets. }\end{array}$ & 4.44 & .645 & 88.8 & High & 2 \\
\hline 6 & $\begin{array}{l}\text { IFRS } 9 \text { address by calculating provisions to } \\
\text { cover both realized losses and foreseeable } \\
\text { future losses. }\end{array}$ & 4.21 & .692 & 84.2 & High & 5 \\
\hline
\end{tabular}




\begin{tabular}{|c|l|c|c|c|c|c|}
\hline 7 & $\begin{array}{l}\text { The bank develops accounting policies to } \\
\text { ensure that it is suitable for the users of the } \\
\text { financial statements. }\end{array}$ & 4.44 & .563 & 88.8 & High & 1 \\
\hline General Standard & $\mathbf{4 . 2 6}$ & $\mathbf{. 2 4 5}$ & $\mathbf{8 5 . 2}$ & High & \\
\hline
\end{tabular}

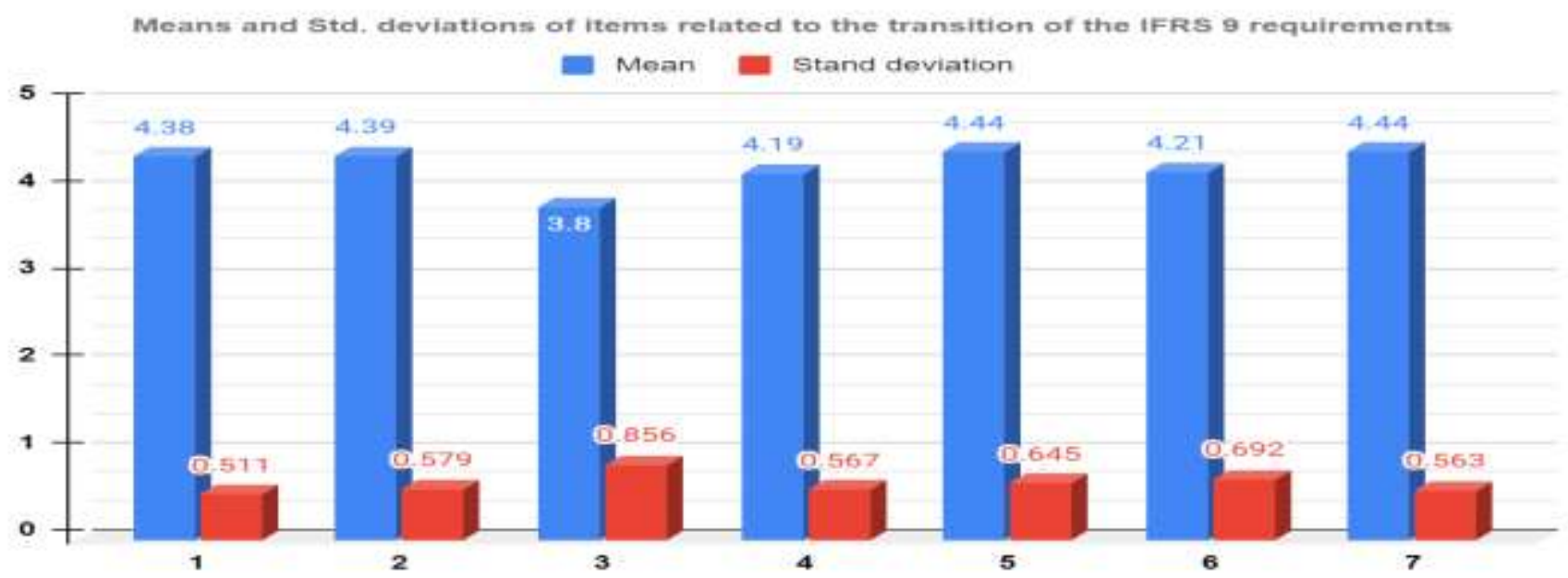

Table (5) shows that transition of the IFRS 9 is relatively high with an overall average of $(4,26)$ and a standard deviation of (0.245). It is noticed that the sample's trends are positive towards all the above-mentioned elements, as its arithmetic averages are greater than the mean of the measuring instrument (3.5).

\subsubsection{The extent of the Suitability of the Quality of Financial Reporting}

Table 6: Means and Std. deviations of items related to the suitability of the quality of financial reporting

\begin{tabular}{|c|l|c|c|c|c|c|}
\hline $\begin{array}{c}\mathbf{N} \\
\mathbf{0}\end{array}$ & \multicolumn{1}{|c|}{ Paragraphs } & Mean & $\begin{array}{c}\text { Stand } \\
\text { deviation }\end{array}$ & $\begin{array}{c}\text { Relative } \\
\text { importance }\end{array}$ & $\begin{array}{c}\text { Applicat } \\
\text { ion-level }\end{array}$ & Rank \\
\hline 1 & $\begin{array}{l}\text { The bank strives to be honest in presenting all accounting procedures } \\
\text { that it follows. }\end{array}$ & 4.42 & .679 & 88.4 & High & 1 \\
\hline 2 & $\begin{array}{l}\text { The bank in the presentation of all financial statements related to } \\
\text { customers. }\end{array}$ & 4.28 & .811 & 85.6 & High & 2 \\
\hline 3 & $\begin{array}{l}\text { The bank can obtain financial information related to the accounting } \\
\text { transactions in a relatively short time }\end{array}$ & 4.07 & .828 & 81.4 & High & 5 \\
\hline 4 & $\begin{array}{l}\text { The bank relies when making its decisions on the speed with which } \\
\text { financial information becomes available. }\end{array}$ & 4.27 & .625 & 85.4 & High & 3 \\
\hline 5 & $\begin{array}{l}\text { The mechanism of accounting procedures followed contributes to } \\
\text { generating feedback for decision-making. }\end{array}$ & 4.13 & .686 & 82.6 & High & 4 \\
\hline General Standard & $\mathbf{4 . 2 3}$ & .341 & $\mathbf{8 4 . 6}$ & High & \\
\hline
\end{tabular}




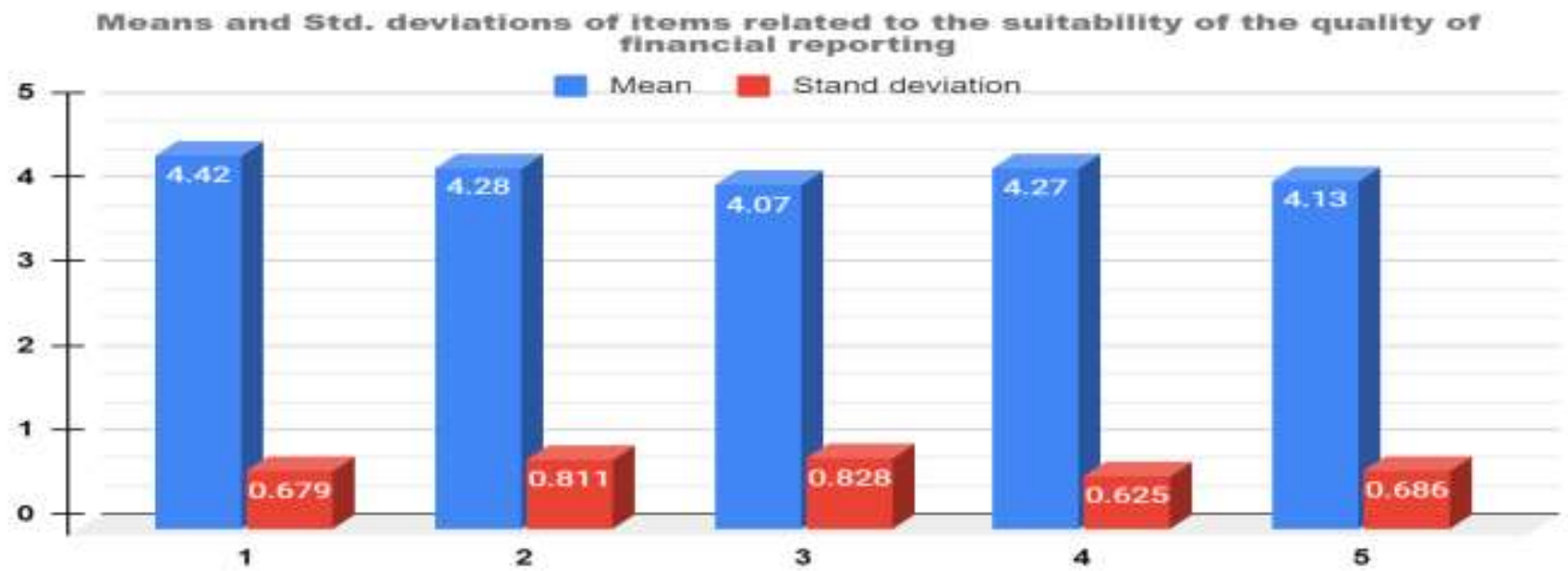

Table (6) shows that the general standard for the quality of financial reporting information in Yemeni commercial banks is high, with a total average of $(4$, $23)$ and relative importance $(84.6 \%)$. It is noticed that

the sample's trends are positive towards all the abovementioned elements, as its arithmetic averages are greater than the mean of the measuring instrument (4).

5.3.3 The extent of the Reliability of the Quality of Financial Reporting Information.

\begin{tabular}{|c|c|c|c|c|c|c|}
\hline \multicolumn{7}{|c|}{ Table 7: Means and Std. deviations of items related to the quality of financial reporting } \\
\hline $\begin{array}{l}\mathbf{N} \\
\mathbf{o}\end{array}$ & Paragraphs & Mean & $\begin{array}{c}\text { Stand. } \\
\text { deviatio } \\
\mathbf{n}\end{array}$ & $\begin{array}{c}\text { Relative } \\
\text { importanc } \\
\text { e }\end{array}$ & $\begin{array}{c}\text { Applicat } \\
\text { ion- } \\
\text { level }\end{array}$ & $\begin{array}{c}\operatorname{Ran} \\
\mathbf{k}\end{array}$ \\
\hline 1 & $\begin{array}{l}\text { Accounting information systems provide permanent } \\
\text { matching in the balances of the balance sheet items. }\end{array}$ & 3.91 & .734 & 78.2 & High & 6 \\
\hline 2 & $\begin{array}{l}\text { The bank is keen on honesty in presenting all financial } \\
\text { statements }\end{array}$ & 4.08 & .916 & 81.6 & High & 5 \\
\hline 3 & $\begin{array}{l}\text { The bank discloses its accounting policy related to its } \\
\text { various financial dealings. }\end{array}$ & 4.31 & .690 & 86.2 & High & 1 \\
\hline 4 & $\begin{array}{l}\text { The financial reports include sufficient, correct, and useful } \\
\text { information to help the bank make decision }\end{array}$ & 4.15 & .732 & 83 & High & 3 \\
\hline 5 & $\begin{array}{l}\text { Accounting information systems provide a permanent } \\
\text { match in the balances of financial reports }\end{array}$ & 4.22 & .520 & 84.4 & High & 2 \\
\hline 6 & $\begin{array}{l}\text { The financial reporting information provided by the bank is } \\
\text { accurate. }\end{array}$ & 4.14 & 601 & 82.2 & High & 4 \\
\hline & General Standard & 4.14 & .304 & 82.2 & High & \\
\hline
\end{tabular}




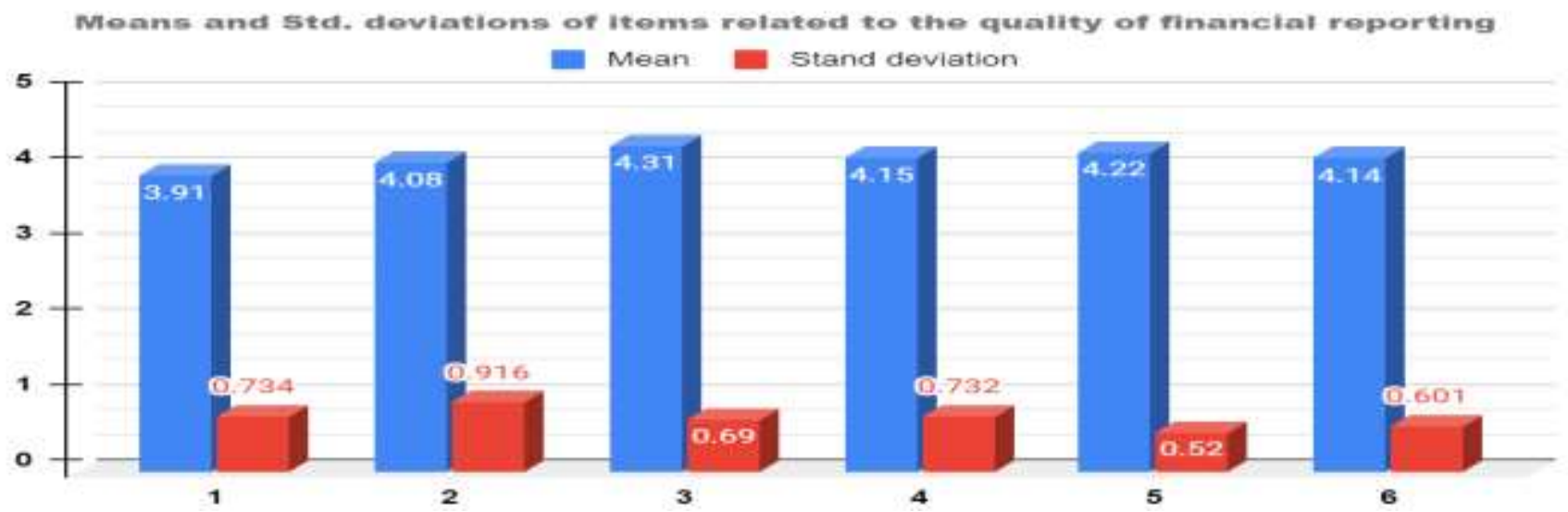

Table (7) shows that the general standard for the reliability of the quality of financial reporting information in Yemeni commercial banks is high, with a total average of $(4,14)$, and relative importance $(82.2 \%)$ as well as a standard deviation $(0.304)$. It is noticed that the sample's trends are positive towards all the above-mentioned elements, as its arithmetic averages are greater than the mean of the measuring instrument (3.5).

\section{TESTING THE HYPOTHESES OF THE STUDY}

H01: There is no impact of the IFRS 9 transition on the suitability of the quality of financial reporting information in Yemen commercial banks.

\begin{tabular}{|c|c|c|c|c|c|c|c|c|c|}
\hline \multicolumn{9}{|c|}{ Table 8: Results of a first sub hypothesis test } \\
\hline $\begin{array}{c}\text { Independent } \\
\text { variable }\end{array}$ & \multicolumn{3}{|c|}{ Model Summary } & \multicolumn{2}{|c|}{ ANOVA } & \multicolumn{4}{c|}{ Coefficient } \\
\hline IFRS9 & $\begin{array}{c}\text { R- } \\
\text { value }\end{array}$ & $\begin{array}{c}\text { R } \\
\text { Square }\end{array}$ & $\begin{array}{c}\text { Adjusted R } \\
\text { Square }\end{array}$ & $\begin{array}{c}\text { F } \\
\text { calculated }\end{array}$ & F & B & $\begin{array}{c}\text { Std. } \\
\text { error }\end{array}$ & $\begin{array}{c}T \\
\text { calculated }\end{array}$ & Sig \\
\cline { 2 - 10 } & 0.756 & 0.549 & .451 & 5.425 & 0.000 & 0.872 & 1.334 & 8.604 & .0 .002 \\
\hline
\end{tabular}

Table (8) indicates that the value of the correlation coefficient is $(\mathrm{R}=0.756)$, which means that there is a positive effect between the application of IFRS 9 and the appropriateness of the quality of financial reports in commercial banks. The significance level $(\mathrm{Sig}=0.002)$ is less than $(0.05)$. Therefore, this tested hypothesis has been replaced by the first alternative. This indicates a transitional effect of IFRS 9 on the appropriateness of the quality of financial reporting information in Yemeni commercial banks. Researchers believe this is logical and realistic in light of the IFRS9 transmission.

H02: There is no impact of the IFRS 9 transition on the reliability of the quality of financial reporting information in Yemen commercial banks.

\begin{tabular}{|c|c|c|c|c|c|c|c|c|c|}
\hline \multicolumn{10}{|c|}{ Table 9: Results of a second sub hypothesis test } \\
\hline Independent variable & \multicolumn{3}{|c|}{ Model Summary } & \multicolumn{2}{|c|}{ ANOVA } & \multicolumn{4}{|c|}{ Coefficient } \\
\hline \multirow[t]{2}{*}{ IFRS9 } & $\begin{array}{c}\text { R- } \\
\text { value }\end{array}$ & $\begin{array}{c}\mathrm{R} \\
\text { square }\end{array}$ & $\begin{array}{c}\text { Adjusted } \\
\text { R } \\
\text { Square }\end{array}$ & $\begin{array}{c}\mathrm{F} \\
\text { calculated }\end{array}$ & $\mathrm{F}$ & B & $\begin{array}{l}\text { Std. } \\
\text { error }\end{array}$ & $\begin{array}{c}\mathrm{T} \\
\text { calculated }\end{array}$ & Sig \\
\hline & 0.840 & .642 & .348 & 11.020 & .001 & .892 & .675 & 5.877 & .000 \\
\hline
\end{tabular}

Table (9) indicates that the value of the correlation coefficient is $(\mathrm{R}=0.840)$, which means that there is a positive impact between the transition of IFRS 9 and the reliability of the quality of financial reporting. The significance level $(\mathrm{Sig}=0.000)$ is less than (0.05). Therefore, we reject the null hypothesis (H0) and accept the alternative hypothesis (Ha). This indicates that there is an impact of the adoption of IFRS 9 represented by Yemen commercial banks on the reliability of the quality of financial reporting information in Yemeni commercial banks. 


\section{CONCLUSION}

The result of the study there is a positive relationship between the impact of the transition of the International Financial Reporting Standard IFRS9 and the suitability and reliability of the quality of financial reporting in Yemen commercial banks. The study also indicated that the clear focus by commercial bank administrations on the bank is obligated to create a contingency reserve for future losses on all the bank's financial assets and that the financial liabilities are classified at fair value through profit or loss. Moreover, the bank classifies financial assets as measured subsequently at cost depleted. The findings of the suitability and reliability of the quality of financial reporting are applied fairly and honestly, as well as free from errors and bias. This indicates that there is an impact of the compliance of Yemen commercial banks on the recognition, classification, and measures of financial instruments and operations following the IFRS 9 requirements on suitability and the reliability of the quality of financial reporting.

Researchers' recommendations are based on the results of the study that is to raise awareness of financial managers and accountants in all sectors of Yemen commercial banks the importance of transition IFRS 9 because of its direct impact on improving the suitability and reliability of the quality of financial reporting information in Yemen commercial banks. As well as conducting a similar study on other economic sectors in the Yemeni environment for comparison to identify similarities and differences between these sectors in adopting the IFRS9 regarding the suitability and reliability of the quality of financial reporting information. Moreover, the number of respondents should be increased. Moreover, it would be useful for future research to investigate the factors affecting the transition of IFRS 9 to Yemen.

\section{REFERENCE}

1. Owolabi, A., \& Iyoha, F. O. (2012). Adopting international financial reporting standards (IFRS) in Africa: Benefits, prospects and challenges. African Journal of Accounting, Auditing and Finance, 1(1), 7786.

2. Al Khresat, A. S., \& Almubaydeen, T. H. (2019). The Impact of the Application of IFRS9 on the Faithful Representation of Financial Accounting Information in Jordanian Commercial Banks. International Journal of Business and Management, 14(3), Pages 88-97.

3. Alali, F., \& Cao, L. (2010). International financial reporting standards-credible and reliable? An overview. Advances in Accounting, 26(1), 79-86.

4. Otusanya, O. J., Lauwo, S., \& Ajibolade, S. O. (2013). An investigation of corporate executive fraud by CEOs in the Nigerian banking sector. African Journal of Accounting, Auditing and Finance, 2(1), 65-89.
5. Alhaija, M. F. (2012). The Adoption of IFRS 9 in the Jordanian Banking Sector: Are Accountants Ready to Adopt by Understanding the Recognition and Measurement. International Journal of Economics and Finance Studies, Forthcoming. https://ssrn.com/abstract $=2012418$.

6. Alkhresat, A. S., \& Almubaydeen, T. H. (2019). The Impact of the Application of International Standard for Financial Reporting No (9) on the Faithful Representation of Financial Accounting Information in Jordanian Commercial Banks. International Journal of Business and Management, 14(3).

7. Beerbaum, D. (2015). Significant increase in credit risk according to IFRS 9: implications for financial institutions. International Journal of Economics \& Management Sciences, 4(9), 1-3.

8. Beerbaum, D., \& Piechocki, M. (2016). IFRS 9 for Financial Institutions-The Case for IFRS and FINREP Taxonomies-A Conceptual Gap Analysis. Maciej, IFRS,pp 80-90. 9.

9. Lay, T. A., \& Jusoh, R. (2012). Business Strategy, Strategic Role of Accountant, Strategic Management Accounting and their Links to Firm Performance: An Exploratory Study of Manufacturing Companies in Malaysia. Asia-Pacific Management Accounting Journal, 7(1), 59-94.

10. Bhattacharjee, S. (2009), Problems of adoption and application of international financial reporting standards (IFRS) in Bangladesh. International Journal of Business and Management, 4(12), 165.

11. BPP Learning Media [BPP] (2014). Paper F7 Financial Reporting Study Text for exams up to June 2015. BPP Learning, London.

12. Gebhardt, G. (2016). Impairments of Greek government bonds under IAS 39 and IFRS 9: A case study. Accounting in Europe, 13(2), 169-196.

13. Giner, B., \& Mora, A. (2019). Bank loan loss accounting and its contracting effects: the new expected loss models. Accounting and Business Research, 49(6), 726-752.

14. Groff, M. Z., \& Mörec, B. (2020). IFRS 9 transition effect on equity in a post bank recovery environment: the case of Slovenia. Economic Research-Ekonomska Istraživanja, 1-17.

15. Habawal, Karan \& Alokdeh, Saleh K. (2018). The Impact of Applying IFRS (9) on Investors' Decisions: An Applied Study on the Companies Listed on Amman Stock Exchange (ASE), International Review of Management and Business Research, Vol. 7 Issue.2.

16. Hashim, N., Li, W., \& O'Hanlon, J. (2016). Expectedloss-based accounting for impairment of financial instruments: The FASB and IASB proposals 2009-2016. Accounting in Europe, 13(2), 229-267.

17. Herath, S. K., \& Albarqi, N. (2017). Financial reporting quality: A literature review. International Journal of Business Management and Commerce, 2(2), 1-14.

18. Jermakowicz, E.K., Chen, C.-D. and Donker, H. (2018), "Financial statement effects of adopting IFRS: the Canadian experience", International Journal of Accounting \& Information Management, Vol. 26 No. 4, pp. 466-491. 
19. Khersiat, O. M., \& Alkabbani, R. F. (2020). Impact of the Application of IFRS 9 Standards on the Profits and Losses of Insurance Companies Listed on the Amman Stock Exchange. Academy of Strategic Management Journal, 19(1), 1-7

20. Loew, E., Schmidt, L. E., \& Thiel, L. F. (2019). Accounting for Financial Instruments under IFRS 9First-Time Application Effects on European Banks' Balance Sheets. European Banking Institute Working Paper Series 2019 - no. 48.

21. Nurunnabi, M. (2018). Perceived costs and benefits of IFRS adoption in Saudi Arabia: An exploratory study. Research in Accounting Regulation, 30(2), 166-175.

22. Onali, E., \& Ginesti, G. (2014). Pre-adoption market reaction to IFRS 9: A cross-country event-study. Journal of Accounting and Public Policy, 33(6), 628-637.

23. Owolabi, A. A. (2012). The role of auditors in the financial crisis: an African perspective. African Journal of Accounting, Auditing and Finance, 1(3), 299-308.

24. Saqaf Al-Hayt, Fires Ismail Masoud, \& Shbeita, Muhammad Fawzi Shaker. (2017). The Impact of Applying International Financial Reporting Standard (IFRS 9) on the Quality of the Accounting System Outcomes of the Insurance Companies in Jordan. Zarqa Journal for Research and Studies in Humanities, 341(5693), 1-20.

25. Shields, K., Clacher, I., \& Zhang, Q. (2019). Negative Tone in Lobbying the International Accounting Standards Board. The International Journal of Accounting, 54(03), 1950010.

26. Soderstrom, N. S., \& Sun, K. J. (2007). IFRS adoption and accounting quality: a review. European accounting review, 16(4), 675-702.

27. Yuri Sandi,T. \& Puspitasari, E. (2015). Financial reporting Quality - Before and After IFRS Adoption Using Nice Qualitative Characteristics Measurement. ProcardiaSocial and Behavioral Sciences, 211, 644-652. 